Date of Publication: 27 May 2014

\section{Cunninghamia}

A journal of plant ecology for eastern Australia

\title{
The contribution of vegetation survey and mapping to Herbarium collections and botanical knowledge: a case study from Queensland.
}

\author{
V.J. Neldner \\ Queensland Herbarium, Department of Science, Information Technology, Innovation and the Arts, Brisbane Botanic Gardens, \\ Mt Coot-tha Road, Toowong, Brisbane, Queensland, 4066, AUSTRALIA
}

\begin{abstract}
The Queensland Herbarium Regional Ecosystem Survey and Mapping (QHRESM) program has contributed almost 90000 (89389) specimens to the Queensland Herbarium in Brisbane accounting for $28 \%$ of the specimens added to the Herbarium between 1970 and 2011. These specimens have been collected across all bioregions and vegetation communities in Queensland in a systematic sampling program driven by the requirement to sample comprehensively all vegetation communities. The QHRESM's Queensland Herbarium (BRI) specimens represent more than $79 \%$ of the native, and $73 \%$ of the naturalised vascular flora of Queensland, as well as making valuable contributions to the bryophytes, lichens and liverworts collections. The data and specimens collected enhance our ability to assess local, state and continental-scale plant diversity, and will be used by botanists, ecologists, governments, business and the public for long into the future.
\end{abstract}

Key words: conservation status, floristic composition, Herbarium specimens, modelling of species, Queensland flora, systematic sampling, regional ecosystems, survey and mapping, vegetation

Cunninghamia (2014) 14: 77-87

doi:10.7751/cunninghamia.2014.14.005

\section{Introduction}

Since the late 1940s Australian vegetation scientists have developed a wide variety of vegetation survey, classification and mapping systems (Benson 1995, Sun et al. 1997). Vegetation surveys may target the occurrence of certain plant species or all species present at a site, and range from surveys for individual threatened plant species or specific taxonomic groups, where only certain plants are targeted, through to comprehensive site surveys where all species are documented (Thackway et al. 2008).

Vegetation mapping projects vary in scope and comprehensiveness and in the type of outputs produced. For some projects vegetation maps and associated descriptions are the only products, e.g. the mapping of the vegetation of Western Australia by John Beard (1979), and the vegetation map of Fraser Island (Stanton, 1979). However, vegetation survey and mapping projects can also collect large amounts of systematic ecological data with a wide range of applications, e.g. underpinning benchmarks and technical descriptions for biodiversity offsets, evaluating distribution and conservation status for species listing under legislative provisions, identifying species-rich areas for conservation planning and acquisition, as well as for basic scientific studies in plant systematics and ecology.

Queensland has a diverse range of landscapes, vegetation and ecosystems in its extensive 1,730,000 $\mathrm{km}^{2}$ area. Queensland vegetation ranges structurally from rainforests in the Wet 
Tropics bioregion to sparse-forblands and open-hummock grasslands in the Channel Country bioregion (Sattler and Williams 1999). The development of a systematic and efficient method of mapping and surveying Queensland's diverse regional ecosystems has been refined over a number of years (Neldner et al. 2012, Neldner and Butler 2008). However, from the outset, the Queensland Herbarium Regional Ecosystem Survey and Mapping program (QHRESM) program has always been seen as an opportunity to obtain a comprehensive and systematic survey of the vegetation of Queensland, providing detailed floristic and structural data that can be used for a number of purposes as described above. The minimum field data required for ground truthing for mapping purposes is limited to the ecologically dominant layer, for example in wooded communities the tree layer (Neldner and Howitt 1991). The detailed vegetation site data form CORVEG, (the Queensland Herbarium ecological site database, which currently includes data from 12,502 validated and 7,075 unvalidated sites (Neldner et al. 2012). Collecting to improve knowledge of the distribution of Queensland's plants and vouchering specimens to confirm plant identities (all threatened plants and any new records for a 1:100 000 map sheet) has also been part of the methodology and has contributed a large number of specimens to the Queensland Herbarium.

In this paper, the contribution of the QHRESM program to knowledge of the Queensland flora through the provision of botanical specimens is examined. The QHRESM program includes all projects since 1970 that result in the production of a vegetation or regional ecosystem paper map or digital map coverage at a variety of scales (eg. 1:25 000 coastal mapping through to 1:1 000000 scale western region mapping), and frequently with a report describing the map legend and vegetation units. The program also includes surveys of particular restricted vegetation types, such as groundwater springs (Fensham and Fairfax 2000), semi-evergreen vine thickets (Fensham 1995) and Astrebla grasslands (Fensham et al. 2000) that did not necessarily produce a final vegetation map of all communities.

\section{History of Queensland Herbarium Regional Ecosystem Survey and Mapping (QHRESM)}

Botanists from the Queensland Herbarium provided ecological input into the multi-disciplinary CSIRO Land Research Series and Western Arid Region Land Use Study (WARLUS) in Queensland in the 1960-1970s. A vegetation mapping program for Queensland was devised and implemented with the assistance of Commonwealth funds through the Australian Biological Resources Study in the late 1970s (Neldner 1993a).

From 1970 to 1979, the Queensland vegetation mapping program was predominantly involved in the WARLUS (1:1 M scale), coastal mapping for the Beach Protection Authority (1:25 000), and the Moreton Region Vegetation Map Series (1:100 000). In the period of 1980 to 1994 , large areas of western Queensland were mapped through the Vegetation Survey of Queensland (1:1 M), together with the Cape York Peninsula Land Use Study (1:100 000),
Mackay coast mapping (1:25 000), Darling Downs mapping, Desert Uplands bioregion mapping and continued Southeast Queensland mapping. From 1995 to 1997, there was an active period of mapping in Southeast Queensland under the Forest Agreement process (McAlpine et al. 2005), together with the commencement of regional ecosystem (see Sattler and Williams 1999) mapping in the Brigalow Belt, Einasleigh Uplands and Bartle Frère 1:100 000 map sheet of the Wet Tropics, and surveys of the Mitchell grass, artesian springs and serpentine areas of Queensland. In the final period since 1998, regional ecosystem mapping program activity has concentrated on the eastern bioregions and through the Gulf Plains and Northwest Highlands bioregions.

Forty-three years since its commencement, the mapping of Queensland's vegetation and regional ecosystems is $95 \%$ completed at 1:100 000 or larger scale, and 1386 regional ecosystems have been defined and mapped (Queensland Government 2012). The coverage of regional ecosystems across both pre-cleared environments and remnant vegetation is readily available on the Queensland Government data website (https://data.qld.gov.au/) and has been used increasingly by government, business, landholders and the community for a wide variety of planning (e.g. biodiversity planning assessments for bioregions), regulatory (eg. tree clearing under the Vegetation Management Act 1999), fire hazard risk assessment, and educational uses.

\section{Methods}

The Queensland Herbarium (International Herbarium acronym BRI, ie. short for Brisbane) was one of the first herbaria in Australia to document its specimens in a database, HERBRECS (Johnson 1991). HERBRECS is a corporate Oracle database consisting of 826,374 specimen records (on 7th November 2013). HERBRECS was interrogated on the basis of the primary specimen collector to find those specimens collected during survey and mapping projects in Queensland in the last 43 years. Most of the selected collectors were primarily involved in survey and mapping projects on a full time basis; all specimens collected by them could be attributed to this activity. However, some collectors were involved in a number of different projects or submitted specimens collected in a private capacity. These collections were excluded with the aid of ArcGIS mapping software to identify collections not associated with the program. The author, who was part of the QHRESM program from 1980 and managed the program from 1996 to 2004, used his knowledge of the collectors and their projects to refine the selected list down to those attributable to survey and mapping projects. Once the specimens that were attributed to survey and mapping activities were distinguished, they were analysed by criteria including taxonomic family, genera, date of collection, conservation status and native status. The data manipulation, statistical summarisation and graphics production were performed within the R computing environment (http://www.r-project.org/). 

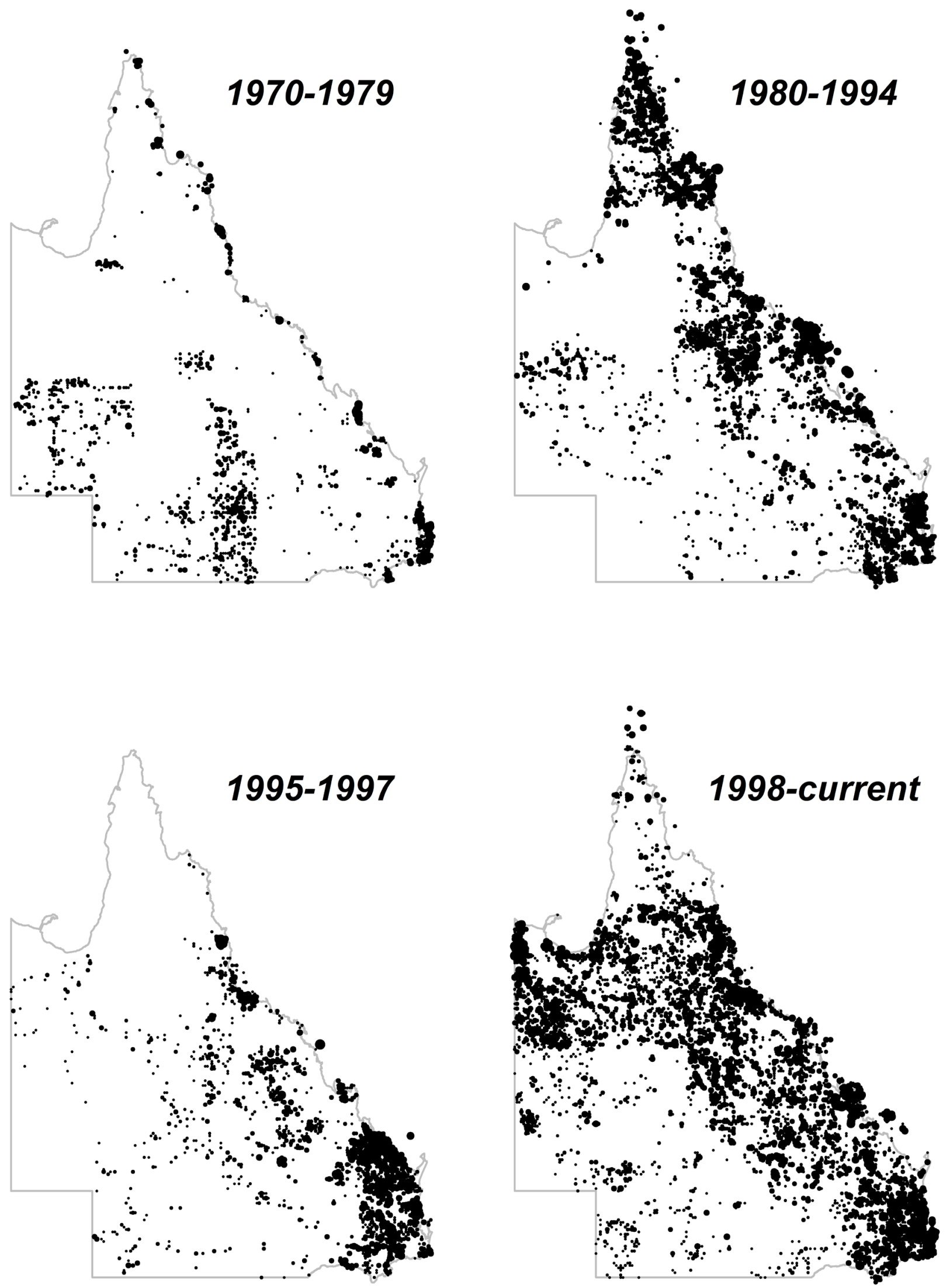

Fig. 1. Geographic distribution and density of BRI Herbarium specimens collected during significant phases of the QHRESM program.The number of specimens in each $80 \mathrm{~km}^{2}$ grid cell $(0.083$ degree latitude by 0.083 degree longitude $)$ was calculated. For each cell, the dot size is proportional to the logarithm of the specimen count. 
The geographic distributions of the specimens collected during the QHRESM program were mapped on the basis of relevant periods (years collected) and the density of collections (Figure 1) using the count of specimens for each $80 \mathrm{~km}^{2}$ grid cell ( 0.083 degree latitude by 0.083 degree longitude). This map illustrates the distribution and intensity of collecting of BRI specimens through the QHRESM program for various time periods.

\section{Results}

About 50 botanists and technicians involved in QHRESM projects have lodged specimens at BRI Herbarium. About 20 collectors each with more than 1000 BRI specimens from the QHRESM program are listed individually in Table 1 together with the number of specimens lodged; a combined number is given for other collectors. For all collectors, the specimens that were not collected as part of QHRESM program have been removed from the analysis.

Also listed in Table 1 are data on the conservation $(\mathrm{E}=$ Endangered, V = Vulnerable, NT = Near Threatened, LC $=$ Least Concern listing under the Nature Conservation Act 1992) and native status of the taxa. Specimens from 369 families were collected during the program from 1970-2011, with the majority being vascular plants and least concern (LC) native species.
Table 2 lists the number of specimens collected as part of the QHRESM program listed alphabetically by family (where $>1000$ specimens), and other plant groups. The QHRESM BRI Herbarium collections made up $28 \%$ of the overall collections for native plants, $31 \%$ of the non-native plant collections and only $16.5 \%$ of the threatened plant specimens. For all of the largest Angiosperm families at least 20\% of the specimens came from QHRESM, with higher proportions $(>30 \%)$ from the Poaceae, Cyperaceae, Malvaceae and Chenopodiaceae. These families generally dominate the ground layer and frequently require identification in the laboratory. The QHRESM specimens made up a higher proportion $(31 \%)$ of non-native specimens collected and a lower proportion of threatened taxa $(16 \%)$.

The number of species collected by the QHRESM program is compared to the total flora for Queensland as documented by Bostock and Holland (2010) for the major plant groups in Table 3, and the largest families and genera in Table 4.

The frequency of Angiosperm taxa collected as part of QHRESM program and lodged as BRI Herbarium specimen ranges from 943 taxa represented by only a single specimen, to taxa represented by more than 100 specimens (Table 5) not included in Figure 2.

The number of specimens added to BRI by the QHRESM program from 1970 to 2011 was 89389 specimens (28\% of the total of 316982 ). Figure 2 shows the number of specimens

Table 1. Primary collector and number of QHRESM specimens by Threat status, non-native and undescribed taxa status incorporated as BRI Herbarium specimens from collections made during the survey and mapping program up to December 2011. Threat status E = Endangered, V = Vulnerable, NT = Near Threatened, LC = Least Concern listing under the Nature Conservation Act 1992. Undescribed taxa $=$ specimens assigned to a genus and phrase name

\begin{tabular}{|c|c|c|c|c|c|c|c|}
\hline Primary Collector & Total & $\mathbf{E}$ & $\mathbf{V}$ & NT & LC & Non-native & Undescribed taxa \\
\hline Bean A.R. & 14897 & 94 & 214 & 159 & 12068 & 2362 & 117 \\
\hline Batianoff G.N. & 12448 & 19 & 89 & 112 & 9726 & 2502 & 66 \\
\hline Thompson E.J. & 10365 & 20 & 53 & 79 & 9506 & 707 & 270 \\
\hline Clarkson J.R. & 5906 & 6 & 41 & 50 & 5493 & 316 & 80 \\
\hline Fensham R.J. & 5863 & 53 & 63 & 48 & 5202 & 497 & 79 \\
\hline Cumming R.J. & 3971 & 8 & 21 & 63 & 3469 & 410 & 55 \\
\hline Booth R. & 3180 & 2 & 7 & 22 & 3030 & 119 & 88 \\
\hline Neldner V.J. & 2822 & 0 & 8 & 15 & 2620 & 179 & 39 \\
\hline Fox I.D. & 2452 & 1 & 4 & 10 & 2212 & 225 & 23 \\
\hline Fell D.G. & 2386 & 2 & 27 & 65 & 2259 & 33 & 76 \\
\hline Grimshaw P.G. & 2320 & 24 & 66 & 92 & 2107 & 31 & 29 \\
\hline Pollock A.B. & 2177 & 4 & 16 & 15 & 1898 & 244 & 15 \\
\hline McDonald W.J. & 2144 & 10 & 43 & 84 & 1943 & 64 & 27 \\
\hline Stephens K.M. & 1930 & 4 & 7 & 14 & 1669 & 236 & 8 \\
\hline Kemp J.E. & 1922 & 3 & 6 & 13 & 1764 & 136 & 28 \\
\hline Johnson D.C. & 1332 & 0 & 4 & 1 & 1265 & 62 & 14 \\
\hline Purdie R.W. & 1350 & 0 & 5 & $\begin{array}{l}5 \\
82\end{array}$ & 1306 & 34 & 22 \\
\hline $\begin{array}{l}\text { Hunter J.T. } \\
\text { Turnin GPP }\end{array}$ & $\begin{array}{l}1284 \\
1157\end{array}$ & $\begin{array}{l}2 \\
0\end{array}$ & 22 & $\begin{array}{l}82 \\
7\end{array}$ & 1158 & 20 & 45 \\
\hline $\begin{array}{l}\text { Turpin G.P. } \\
\text { Other^}^{\wedge}\end{array}$ & $\begin{array}{l}1157 \\
9483\end{array}$ & $\begin{array}{l}0 \\
45\end{array}$ & $\begin{array}{l}1 \\
81\end{array}$ & $\begin{array}{l}7 \\
79\end{array}$ & $\begin{array}{l}1102 \\
8477\end{array}$ & $\begin{array}{l}47 \\
801\end{array}$ & 16 \\
\hline TOTAL & 89389 & 297 & 778 & 1015 & 78274 & 9025 & $\begin{array}{l}110 \\
\mathbf{1 2 0 7}\end{array}$ \\
\hline
\end{tabular}

${ }^{\wedge}$ Other includes the BRI collections of Addicott E.P., Appelman C.N., Bailey L., Baumgartner D.J., Beeston, G.R., Boyland, D.E., Brushe J., Butler D.W., Cartan H., Dillewaard H.A., Dowling R.M., Durrington, L., Edginton M.A., Elsol J.A., Fairfax R.J., Horton S.A., Kahler C., Kelman D.T., Lovatt R., McDonald T.J., Pennay C., Richter D., Ryan T.S., Schmeider M., Sparshott K.M., Sullivan S.C., Thompson S.L., Wilson B.A., Wilson G.W. and Young P.A. 
Table 2. Number of QHRESM specimens (total 89383) listed by major plant family or taxonomic group, showing number of native, non-native and Threatened (E,V,NT) specimens and the proportional contribution to the total BRI Herbarium specimen collections (for 1970-2011).

\begin{tabular}{|c|c|c|c|c|c|c|}
\hline $\begin{array}{l}\text { Family } \\
\text { Poaceae }\end{array}$ & $\begin{array}{l}\text { No. of native } \\
11292\end{array}$ & $\begin{array}{l}\text { \% of total } \\
\text { native } \\
42.5\end{array}$ & $\begin{array}{l}\text { No. of } \\
\text { non-native } \\
1733\end{array}$ & $\begin{array}{l}\text { \% of total } \\
\text { non-native } \\
24.5\end{array}$ & $\begin{array}{l}\text { No. of E, V, } \\
\text { or NT } \\
126\end{array}$ & $\begin{array}{l}\% \text { of total E, } \\
\text { Vor NT } \\
26.3\end{array}$ \\
\hline Myrtaceae & 6160 & 27.7 & 54 & 38.0 & 329 & 22.5 \\
\hline Cyperaceae & 5380 & 39.4 & 238 & 32.2 & 35 & 23.0 \\
\hline Fabaceae & 5310 & 28.2 & 823 & 25.0 & 47 & 20.9 \\
\hline Mimosaceae & 3508 & 24.4 & 155 & 22.0 & 123 & 17.3 \\
\hline Asteraceae & 3226 & 30.2 & 1287 & 24.5 & 107 & 27.9 \\
\hline Rubiaceae & 1857 & 24.3 & 113 & 22.1 & 26 & 12.7 \\
\hline Malvaceae & 1658 & 35.8 & 406 & 28.3 & 3 & 42.9 \\
\hline Sapindaceae & 1543 & 24.5 & 35 & 24.3 & 50 & 12.6 \\
\hline Euphorbiaceae & 1520 & 24.8 & 209 & 22.2 & 62 & 15.5 \\
\hline Rutaceae & 1382 & 20.7 & 20 & 35.1 & 80 & 12.9 \\
\hline Phyllanthaceae & 1374 & 28.1 & 20 & 20.6 & 30 & 15.7 \\
\hline Lamiaceae & 1202 & 26.2 & 207 & 25.4 & 30 & 14.5 \\
\hline Apocynaceae & 1167 & 21.5 & 234 & 28.7 & 72 & 21.9 \\
\hline Chenopodiaceae & 1141 & 30.4 & 23 & 17.6 & 2 & 6.3 \\
\hline Proteaceae & 1017 & 20.7 & 0 & 0 & 79 & 12.6 \\
\hline Other Angiosperms\# & 28782 & 25.7 & 3444 & 58.6 & 824 & 16.5 \\
\hline Gymnosperms & 123 & 6.4 & 123 & 15.5 & 0 & 0 \\
\hline Pteridophyta & 1819 & 11.2 & 24 & 5.6 & 27 & 6.4 \\
\hline Bryophyta & 137 & 4.6 & 0 & 0 & 0 & 0 \\
\hline Lichens \& Liverworts & 522 & 3.9 & 0 & 0 & 38 & 0 \\
\hline Algae & 47 & 3.5 & 0 & 0 & 0 & 0 \\
\hline Fungi & 320 & 3.8 & 0 & 0 & 0 & 0 \\
\hline Total & 89389 & 28.2 & 9025 & 30.9 & 2090 & 16.5 \\
\hline
\end{tabular}

Other Angiosperms is represented by 257 families, Gymnosperms by 4 families, Pteridophytes by 34 families, Bryophytes by 17 families, Lichens and Liverworts by 40 families, Algae by 2 families, and fungi by 24 families.

Table 3. Major plant groups showing number of taxa collected by QHRESM program specimens compared to total for Queensland.

$\begin{array}{llllll} & \begin{array}{l}\text { Species identified } \\ \text { from QHRESM } \\ \text { program }\end{array} & \begin{array}{l}\text { Taxa identified } \\ \text { from QHRESM } \\ \text { program }\end{array} & \begin{array}{l}\text { QLD species (Bostock \% QId species } \\ \text { \& Holland 2010) }\end{array} & \begin{array}{l}\text { No. of BRI } \\ \text { collected by } \\ \text { QHRESM program }\end{array} \\ \text { Specimens } \\ \text { Native vascular } & 6549 & 6897 & & 78 & 77519 \\ \text { Naturalised alien } & 918 & 936 & 8449 & 73 & 9015 \\ \text { Angiosperms } & 6308 & 6665 & 8005 & 79 & 75758 \\ \text { Gymnosperms } & 41 & 41 & 62 & 66 & 121 \\ \text { Pteridophyta } & 187 & 190 & 381 & 49 & 43 \\ \text { Bryophytes } & 25 & 25 & 555 & 5 & 198 \\ \text { Lichens \& Liverworts } & 102 & 102 & 1309 & 8 & 11 \\ \text { Algae } & 10 & 10 & 1505 & 0.01 & 71 \\ \text { Fungi } & 47 & 47 & \text { na } & \text { na } & \end{array}$

Table 4. Number of taxa represented by QHRESM program specimens for selected families and genera with high species diversity, and comparison with total taxa for Queensland (Bostock \& Holland 2010).

$\begin{array}{llllll}\text { Family/genera } & \text { No of Species } & \text { No of Taxa } & \text { No of QLD species } & \text { \% Qld species } & \text { No. of } \\ \text { Poaceae } & 550 & 579 & 629 & 87 & 11216 \\ \text { Myrtaceae } & 524 & 543 & 601 & 87 & 6202 \\ \text { Fabaceae } & 376 & 409 & 474 & 79 & 4866 \\ \text { Acacia }+ \text { Vachellia } & 258 & 272 & 308 & 84 & 3121 \\ \text { Corymbia }+ \text { Eucalyptus } & 212 & 225 & 222 & 96 & 3020\end{array}$


Table 5. Frequently recorded QHRESM program taxa with more than 100 specimens in BRI Herbarium

Taxon

Fimbristylis dichotoma (L.) Vahl

Cyanthillium cinereum (L.) H.Rob.

Eucalyptus crebra F.Muell.

Aristida holathera Domin var. holathera

Alphitonia excelsa (Fenzl) Benth.

Enneapogon lindleyanus (Domin) C.E.Hubb.

Corymbia clarksoniana (D.J.Carr \& S.G.M.Carr) K.D.Hill \& L.A.S.Johnson

Panicum effusum R.Br.

Allocasuarina littoralis (Salisb.) L.A.S.Johnson

Schizachyrium fragile (R.Br.) A.Camus

Cyperus difformis $\mathrm{L}$.

Melaleuca viridiflora Sol. ex Gaertn. var. viridiflora

$\begin{array}{llll}\text { Family } & \begin{array}{l}\text { No. of BRI } \\ \text { specimens }\end{array} & \begin{array}{l}\text { No. of } \\ \text { Bioregions } \\ \text { recorded }\end{array} & \begin{array}{l}\text { No. of CORVEG } \\ \text { records }\end{array} \\ \text { Cyperaceae } & 177 & 13 & 800 \\ \text { Asteraceae } & 146 & 12 & 1395 \\ \text { Myrtaceae } & 145 & 10 & 1670 \\ \text { Poaceae } & 143 & 13 & 500 \\ \text { Rhamnaceae } & 132 & 12 & 1892 \\ \text { Poaceae } & 123 & 12 & 463 \\ \text { Myrtaceae } & 118 & 11 & 890 \\ \text { Poaceae } & 108 & 13 & 710 \\ \text { Casuarinaceae } & 107 & 8 & 648 \\ \text { Poaceae } & 106 & 13 & 804 \\ \text { Cyperaceae } & 105 & 13 & 88 \\ \text { Myrtaceae } & 103 & 9 & 945\end{array}$

\section{Discussion}

collected through the program each year compared to the total specimens incorporated into the Queensland Herbarium for the same year. Specimens from the program made up only $1 \%$ of the total number added to the Herbarium in 1973, up to a maximum of $49 \%$ of the specimens incorporated in 1994 .

A large number of Angiosperm taxa were only collected and lodged in BRI by the QHRESM program a few times, while there were 12 species that were represented by more than 100 specimens in BRI. The frequency of BRI collection of individual Angiosperm taxa during the QHRESM program is illustrated in Figure 3.

As a measure of the geographic distribution of the QHRESM collections, the proportion of the total Herbarium specimens that are QHRESM collections in each of the 15 Pastoral Districts that make up Queensland is shown in Figure 4. At least $15 \%$ and up to $52 \%$ of BRI specimens for every Pastoral District were collected through the QHRESM program.

\section{Herbarium specimens incorporated 1970-2011}

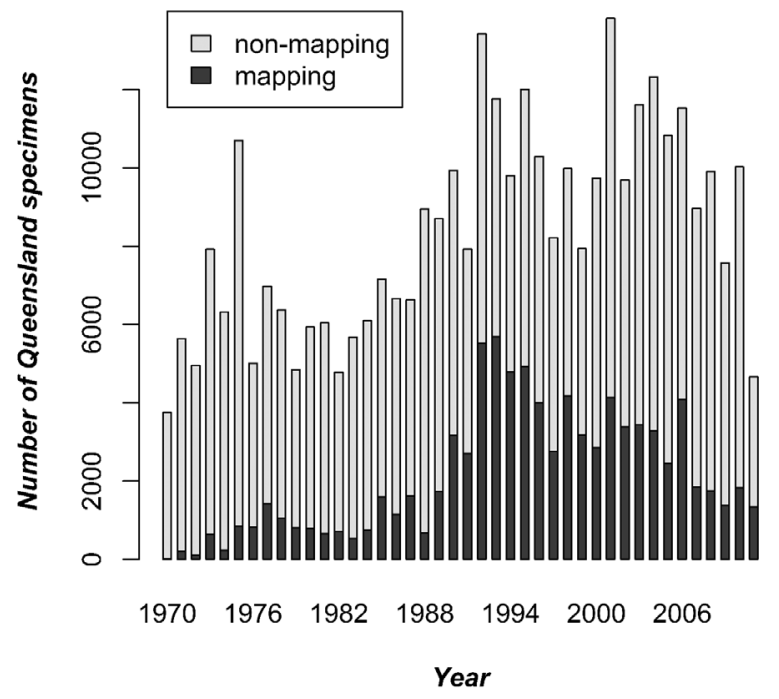

Fig. 2. Stacked bar chart of number of specimens collected through the QHRESM program by each year compared to the total specimens incorporated into BRI Herbarium for the same year.
The results compiled above (particularly Table 1, Figure 1) demonstrate the significant contribution the QHRESM program has had in increasing the knowledge of Queensland's vascular plants through the specimens housed in BRI. Since 1970 , the survey and mapping projects have contributed $28 \%$ of all specimens collected for BRI. During the years activity was occurring under the Cape York Peninsula Land Use Study (CYPLUS) and Southeast Queensland Forest Agreement (SEQFA), more than $40 \%$ of collections were from this program. The QHRESM specimens, together with collections from the biodiscovery plant collecting project (P.I. Forster collections 1994-2003 of 13,808 specimens),

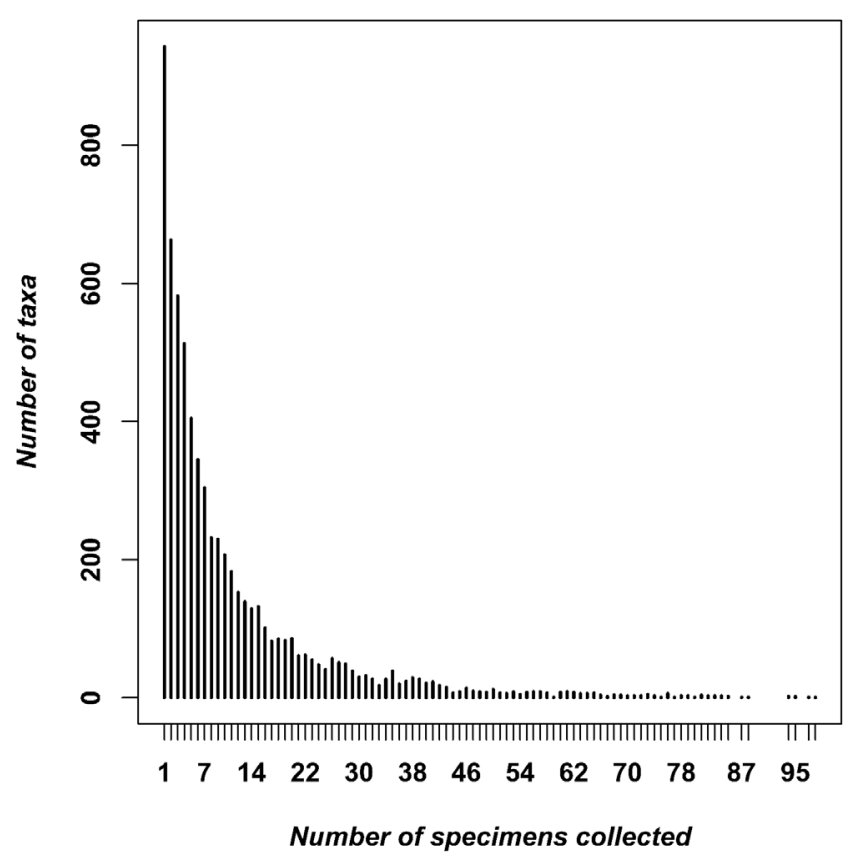

Fig. 3. Histogram of frequency of collection of individual Angiosperm taxa during the QHRESM program. 943 taxa were only collected once; 12 species collected more than 100 times are not included in this figure but are listed in Table 5. of 1992-1999, when the concentrated vegetation mapping 
accounted for more than $50 \%$ of accessions to the Queensland Herbarium during the 1994-2003 period. In addition to BRI specimens, duplicate specimens were also sent to other herbaria worldwide to further taxonomic study.

The QHRESM collections have provided a relatively comprehensive coverage of the overall vascular plant diversity of Queensland. For example over $77 \%$ of the described native and naturalised vascular flora has been collected (Table 3). For the largest families and genera, the QHRESM program plant collections represent more than $79 \%$ of the total Queensland flora, and for the eucalypts $($ Corymbia + Eucalyptus $)$ and acacias (Acacia + Vachellia $)$ which dominate and define the majority of wooded vegetation communities, the percentage representation is higher, greater than 83 and $95 \%$ respectively (Table 4 ).
The vegetation survey and mapping methodology (Neldner et al. 2012) requires the systematic assessment of all layers ie. tree, shrub and ground layers, and ensures that all life forms of vascular plants are inventoried. Table 2 shows a large number of families dominated by herbaceous species. While herbaceous species can frequently add a high number of overall species diversity at a site and are important for building effective surrogates for plant diversity in classification, they are not usually important for defining the vegetation community for mapping purposes, apart from in grasslands, forblands and sedgelands. The high number of herbarium specimens lodged from predominantly herbaceous dominated families indicates that botanists are recording the full vascular plant diversity at a site within the seasonal condition constraints.

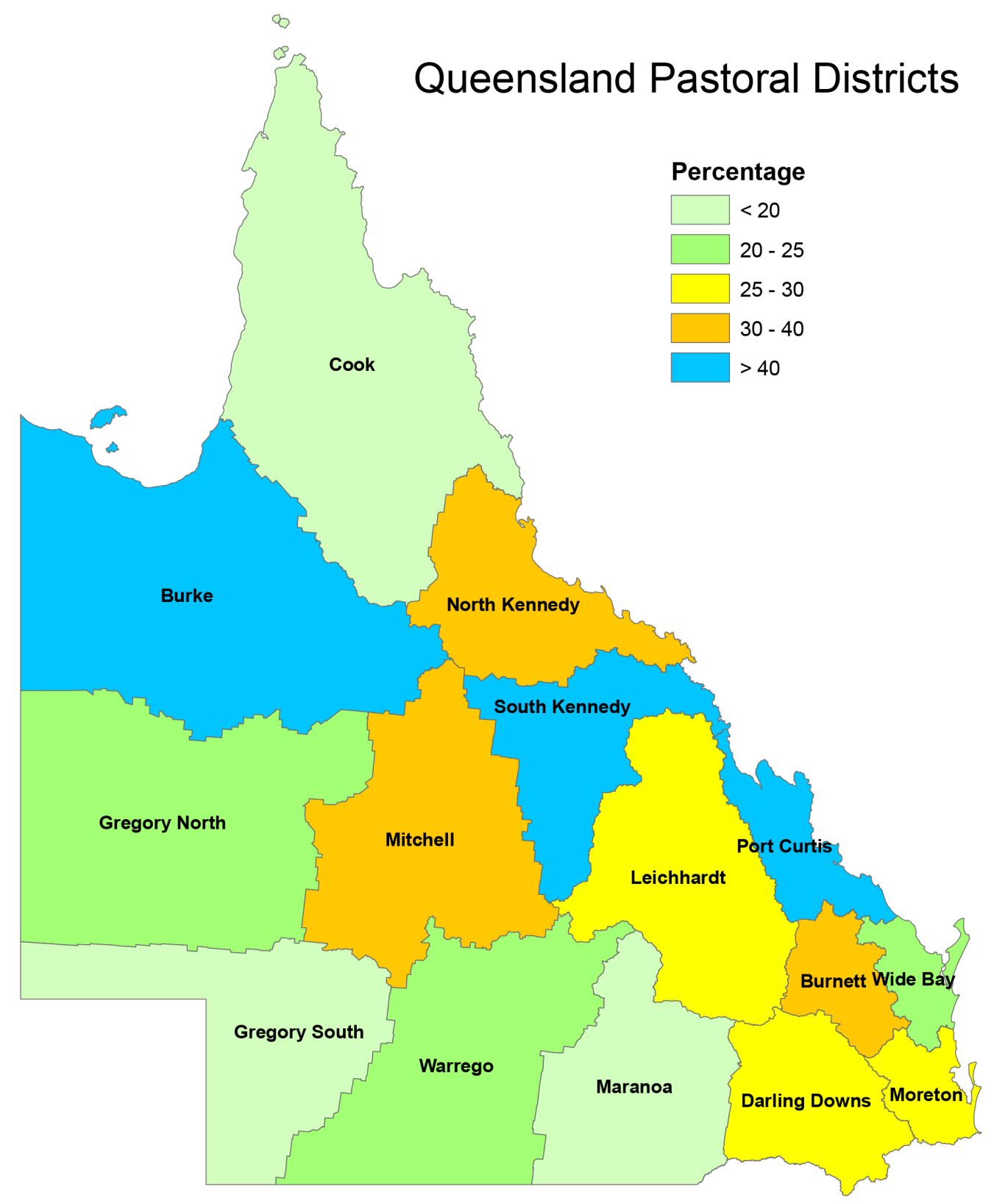

Fig. 4. Map of Queensland illustrating the proportion of BRI Herbarium collections derived from the QHRESM program in each Queensland Pastoral District. 
Vascular plants dominate BRI Herbarium collections from the QHRESM program with $96 \%$ of the collections being Angiosperms, $0.15 \%$ Gymnosperms and $2.3 \%$ Pteridophytes. However while the scope of QHRESM is to describe the terrestrial vegetation, there have been significant collections of non-vascular plants: 137 mosses from 17 families, 522 lichens from 40 families, 47 Algae from 2 families, and 320 fungi from 24 families. The comprehensiveness of these nonvascular plants collections varies greatly, and is primarily driven by the interests of the individual botanist.

The QHRESM collections of the vascular flora are dominated by the Poaceae which frequently dominate the ground layer in terms of species and cover, and frequently require collecting for positive identification. Numerous collections have been made of Cyperaceae, Fabaceae, Asteraceae, Malvaceae, Euphorbiaceae, Chenopodiaceae and Phyllanthaceae which also contribute a large amount of species and cover to the ground layer. Prior to broad-scale clearing, $43 \%$ of Queensland was dominated by Eucalypt open forest and woodlands, while the semi-arid areas dominated by Acacia low woodlands and tall shrublands made up $23 \%$ of the state. By 2003 the remnant vegetation had been reduced to $33 \%$ and 16\% respectively (Queensland Government 2008). Hence it is not surprising to see the numerous QHRESM collections of Myrtaceae and Mimosaceae. There are also frequent collections from families such as Myrtaceae, Rubiaceae, Sapindaceae, Rutaceae, Apocynaceae and Proteaceae that have a large number of representatives in the rainforests, which covered $1 \%$ of Queensland in 2003, about half of their pre-clearing distribution.

The QHRESM collections also reflect the plant diversity of Queensland's nearly 8500 native vascular plant species, the largest families of which are the Poaceae (629 species) Myrtaceae (601 species) and Fabaceae (474 species) (Bostock and Holland 2010) (Table 4). The 12 most frequently collected (> 100 specimens) species from the QHRESM program (Table 5) are all widely distributed and abundant species. Seven species are herbs (four Poaceae, two Cyperaceae and an Asteraceae) and occur in 12 or more of the 13 bioregions of Queensland. Eucalyptus crebra and Corymbia clarksoniana are widespread canopy trees (10 and 11 bioregions), while Melaleuca viridiflora (9) and Allocasuarina littoralis (8) can dominate the canopy or occur as subcanopy trees. Alphitonia excelsa (12) is usually a subcanopy tree. As well as being important for defining regional ecosystems, all of these tree species can show significant morphological variation, and these factors together with their widespread distribution explain the high BRI Herbarium specimen collection numbers.

During survey and mapping projects, many more specimens are collected than those that are eventually lodged in herbaria. Most are collected to confirm field identification and discarded once determination is resolved. Specimens of (conservation) least concern plants may be retained as vouchers or if there is no specimen for the taxa held in BRI Herbarium for the 1:100 000 map sheet area. Because of seasonal conditions at the time of surveys some specimens are infertile or of too poor quality to be lodged. Figure 2 shows that the majority of taxa are collected less than 6 times by the QHRESM program. The validated CORVEG database consists of 12,502 sites and 272,899 taxa records with average of 26 species per site. Table 5 demonstrates that generally only $15 \%$ of the CORVEG records of the 12 most collected species are vouchered. This is appropriate given the cost of collecting, identifying, processing, curating and databasing voucher specimens. The current charge by Council of Heads of Australasian Herbaria (CHAH) is $\$ 110$ per hour for plant identification and $\$ 30$ for specimen preparation, databasing and curation.

Herbarium specimens are fundamental to taxonomic research. While it is very difficult to provide an estimate of how many new species were discovered through the QHRESM program, the number of specimens that are only determined to genus level can give some indication of the potential numbers. Queensland Herbarium standards for accepting specimens require them to be fertile specimens (apart from some rainforest specimens) and in a state that they can be identified to species level. From the total of 89,389 BRI specimens collected by the QHRESM program, 1321 specimens could only be identified to a genus, however a further 1207 specimens (1.4\%) have a generic name and phrase name (Table 1), e.g. Acacia sp. (Ronlow Park E.J.Thompson+ 61), and are earmarked as a potentially undescribed taxon. Bebber et al. (2010) found that only $16 \%$ of new species were described within 5 years of first being collected, while the remaining $84 \%$ were described from older specimens, some more than 50 years old. The average time lag for angiosperms was 35 years (Bebber et al. 2014). Hence many of the QHRESM BRI specimens may not be critically examined by taxonomists for many years to come. However so far at least 21 Queensland species described in the last 20 years have been given names honouring botanists involved in the QHRESM program.

Herbarium specimens have a much greater use than only plant systematics. Increasingly specimens are being used to provide genetic material to examine the systematic relationships based on genetics (Herrmann and Hummel 1994) or preserve germplasm (Lister et al. 2010), or in some cases chemical analyses are conducted to examine the phytochemistry, eg. foliar Manganese accumulation (Fernanado et al. 2009) and lead-uptake; pollution documentation; bio-prospecting (Funk 2007). Other information that can be studied from Herbarium specimens includes plant predators e.g. leaf miners, leaf-cutter ants, plant diseases eg. myrtle rust, and fungal/ vascular plant symbionts (Funk 2007 ).

As well as adding to the number of specimens in BRI Herbarium, the QHRESM program has greatly improved the distribution of specimens because the ecological sampling for mapping is stratified to cover all of the different vegetation types present and also to sample across the whole map area. This helps to overcome some of the problems associated with herbarium specimens worldwide which have been found to be generally clumped around specific areas (Moerman and Estabrook 2006, Feeley and Silman 2011) 
and biased towards species that are demographically rare in the field. Thus any estimates of species abundance based on herbarium specimens are inherently biased, and cannot be interpreted as being a predictor of their true abundance in the field (Garcillan and Ezcurra 2011). Table 2 shows that the QHRESM collections make up $28 \%$ of the total collections of native plants with a consistent rate of at least $20 \%$ of the collections across all the major Angiosperm families. However the lower rate of $16.5 \%$ for threatened plants supports the findings of a bias in general herbarium collections to demographically rare plants.

The survey and mapping methodology attempts to ensure all vegetation types are sampled based on their relative distribution in the landscape as determined from remotely sensed imagery (Neldner et al. 1995, 2012). Figure 1 shows the geographic distribution and density of QHRESM program BRI collections. It can be seen that the collections have been made across the whole of Queensland, including a large number of the offshore islands. This is supported by Figure 4 which demonstrates a consistent contribution of at least $15 \%$ (up to $52 \%$ ) of the specimens for a Pastoral District coming from the QHRESM program. The focus areas of the QHRESM program at various time periods described earlier can be clearly seen in Figure 1.

High quality fertile specimens of many (conservation) Least Concern species collected in surveys are discarded after name verification, as there are already adequate specimens for that area in the herbarium. However for Threatened taxa, 2090 specimens (2.3\% of all QHRESM collections) of species listed under the Nature Conservation Act 1992 (http:// www.legislation.qld.gov.au/LEGISLTN/CURRENT/N/ NatureConA92.pdf) were lodged in the Herbarium to improve knowledge of the distribution of these threatened plants. 52\% of the plant taxa listed as threatened have been collected by the QHRESM program with 95 species of Endangered, 224 species of Vulnerable and 244 species of Near Threatened plants collected. In Queensland, herbarium collections of listed species under the Nature Conservation Act 1992 are buffered with the remnant vegetation coverage to provide the essential habitat coverage that is used in regulating clearing under the Vegetation Management Act 1999 (http://www.legislation.qld.gov.au/LEGISLTN/ CURRENT/V/VegetManA99.pdf).

Herbarium specimen and ecological site data are used to define the area of occurrence and extent of occupancy of species assessed under the IUCN criteria (IUCN 2001) to determine conservation status. The increased knowledge of the distribution of Queensland plants has been the primary factor that has allowed for the downgraded listing of 116 formerly Nature Conservation Act 1992 listed species over the last 5 years. Neldner (1993b) documented how the additional specimen data collected through the Cape York Peninsula survey and vegetation mapping project led to the delisting of Neofabricia mjoebergii, Neofabricia sericisepala and Decaschistia peninsularis. Of the 18 Queensland plants de-listed from the Commonwealth Environmental Protection and Biodiversity Conservation Act 1999 on 23 May 2013 and 14 December 2013 http://www.environment.gov.au/ cgi-tmp/publiclistchanges.5b2453194e7b93cb2e3f.html, all apart from Commersonia argentea, had at least one BRI specimen collected through the QHRESM program. Species with five or more QHRESM BRI specimens (Number of CORVEG site records in brackets) were Acacia ramiflora (16), Bothriochloa biloba (3), Brachychiton vitifolius (14), Croton magneticus (1), Digitaria porrecta (1) and Jedda multicaulis (1).

Herbarium specimen records are used extensively for modelling species distributions and scenarios such as the potential impacts of climate change. Rivers et al. (2011) have found that at least 15 specimen locations are required to build accurate range estimates of plant distributions, while Feeley and Silman (2011) found that extra specimens and more systematic collecting is required to accurately model and map species ranges. As can be seen in Figures 1 and 4, the QHRESM program has contributed a large amount of systematic data across Queensland, which is made available to governments, researchers and the general public worldwide through Australia's Virtual Herbarium, the Atlas of Living Australia and the Australian Ecological Knowledge and Observation System (AEKOS) (TERN 2013).

Species distribution and population models are useful for assessing the conservation status, population health and threats to species. Reliable locational data and specimen identification are core to achieving successful models. At each CORVEG site, measures of abundance are recorded for different plant lifeforms: basal area, stem density and cover for trees; stem density and cover for shrubs; and cover for herbaceous plants. These abundance data, together with comprehensive locational and landscape data, represent presence and absence data for suitable taxa. These presenceabsence data provide opportunities for more robust species distribution and population modelling (Barry \& Elith 2006). Guerin and Lowe (2013) used Generalized Additive Modelling (GAM) of ecological site data to produce robust models of species distribution. Presence-absence data is useful to evaluate the predictions of models derived from presence only data (Elith et al. 2006).

The survey and mapping program has been focused on the native vegetation, and particularly sites in the best-on-offer condition. However, the survey method requires all plant species to be recorded at a sample site. Hence the program has also greatly increased our knowledge of the distribution of the non-native flora. Table 1 shows that $10.4 \%$ (9205) of BRI specimens collected by the QHRESM program are non-native species. Table 2 documents that over $30 \%$ of the non-native specimens came through the QHRESM program. Families where the non-native species make a significant proportion of the collections include Solanaceae (33\% of QHRESM collections), Asteraceae (28\%), Caesalpiniaceae (21\%), Amaranthaceae (20\%), Malvaceae (20\%) and Apocynaceae (17\%). Two species of naturalised Pinus species and five species of non-native ferns have been collected. The most frequently collected non-native species were Passiflora suberosa L. (73 specimens), Passiflora foetida L. (72) and Cynodon dactylon (L.) Pers. var. dactylon (71). 
Additionally the CORVEG database contains thousands of records of non-native species that can be used for modelling distribution and populations. As the CORVEG sites are located in the minimally disturbed sites and record quantitative abundance data, they can provide an assessment of impact of non-native species on native vegetation, e.g. percentage of non-native cover which is indicator in the BioCondition assessment method (Eyre et al. 2011). CORVEG data can complement specimen data in documenting the spread over time and space of environmental weeds.

\section{Conclusions}

Over the past 43 years, the QHRESM program has contributed almost 90000 (89389) specimens to BRI Herbarium accounting for $28 \%$ of all specimens added to BRI during this period. These specimens have been collected across all bioregions, pastoral districts and vegetation communities across the state using a systematic sampling approach driven by the requirement to comprehensively sample all vegetation communities. The QHRESM BRI specimens represent more than $79 \%$ of the total native and $73 \%$ of the naturalised vascular flora of Queensland, and make a valuable contribution to the collections of bryophytes, lichens and liverworts. The data and specimens collected enhance the ability to assess local, state and continental scale plant diversity through improved distribution information and ecological knowledge, and provide material for more comprehensive plant taxonomy at both the morphological and genetic level.

The contribution of the QHRESM program is going to be greater than stated in this paper because the survey and mapping program is not yet completed. Furthermore there is a backlog in getting specimens into BRI for completed projects, and a significant lag in describing new species. In summary the data collected as part of the QHRESM program provides a long term legacy that undoubtedly will be used by botanists, ecologists, governments and the public for long into the future.

\section{Acknowledgements}

Peter Bostock and Paul Robins extracted a Queensland subset of the HERBRECS data and provided advice on preliminary analyses of the data. Jack Kelley conducted all of the data analysis in $\mathrm{R}$ and produced the maps and figures, and Rosemary Niehus queried the CORVEG ecological database. Two anonymous referees and an editor provided useful suggestions for improvement.

\section{References}

Barry S. \& Elith J. E. (2006) Error and uncertainty in habitat models. Journal of Applied Ecology 43: 413-23

Beard, J.S. (1979) Vegetation mapping in Western Australia. Journal of the Royal Society of Western Australia 62:75-82.

Bebber, D.P., Carine, M.A., Wood, J.R.I., Wortley, A.H., Harris, D.J., Prance, G.T., Davidse, G., Paige, J., Pennington, T.D., Robson, N.K.B. and Scotland, R.W. (2010) Herbaria are a major frontier for species discovery. Proceedings of the National Academy of Sciences 107: 22169-22171.

Bebber, D.P., Wood, J.R.I., Barker, C. and Scotland, R.W. (2014) Author inflation masks global capacity for species discovery in flowering plants. New Phytologist 201:700-706.

Benson, J. (1995) Sampling, strategies and costs of regional vegetation mapping strategies. The Globe number 43. Journal of the Australian Map Circle 43:18-27.

Bostock, P.D. and Holland, A.E. (eds) (2010) Census of the Queensland Flora 2010. Queensland Herbarium, Department of Environment and Resource Management: Brisbane.

Elith, J., Graham, C. H., Anderson, R. P., Dudı 'k, M., Ferrier, S., Guisan, A., Hijmans, R. J., Huettmann, F., Leathwick, J. R., Lehmann, A., Li, J., Lohmann, L. G., Loiselle, B. A., Manion, G., Moritz, C., Nakamura, M., Nakazawa, Y., Overton, J. McC., Peterson, A. T., Phillips, S. J., Richardson, K. S., ScachettiPereira, R., Schapire, R. E., Sobero'n, J., Williams, S., Wisz, M. S. and Zimmermann, N. E. (2006) Novel methods improve prediction of species' distributions from occurrence data. Ecography 29: 129-151.

Eyre, T.J., Kelly, A.L., Neldner, V.J., Wilson, B.A., Ferguson, D.J., Laidlaw, M.J. and Franks, A.J. (2011). BioCondition: A Condition Assessment Framework for Terrestrial Biodiversity in Queensland. Assessment Methodology Manual. Version 2.1 Department of Environment and Resource Management http://www.derm.qld.gov.au/services_resources/item_details. php?item_id=201784

Feely, K.J. and Silman, M.R. (2011) Keep collecting: accurate species distribution modelling requires more collections than previously thought. Diversity and Distributions (2011): 1-9.

Fensham, R.J. (1995) Floristics and environmental relations of inland dry rainforest in north Queensland, Australia. Journal of Biogeography 22:1047-1063.

Fensham, R.J. and Fairfax, R.J. (2000) Spring wetlands of the Great Artesian Basin, Queensland, Australia. Wetlands Ecology and Management 11:343-362.

Fensham, R.J, Minchin, P.R., Fairfax, R.J., Kemp, J.E., Purdie, R.W., McDonald, W.J.F. and Neldner, V.J. (2000) Broad-scale environmental relations of floristic gradients in the Mitchell grasslands of Queensland. Australian Journal of Botany 48:27-38.

Fernando, D.R., Guymer, G.P., Reeves, R.D., Woodrow, I.E., Baker, A.J. and Batianoff, G.N. (2009) Foliar Mn accumulation in eastern Australian herbarium specimens: prospecting for 'new' Mn hyperaccumulators and potential applications in taxonomy. Annals of Botany 103: 931-939.

Funk, V.A. (2007) 100 Uses For A Herbarium. US National Herbarium http://www.virtualherbarium.org/vh/100UsesASPT. html

Garcillan, P.P. and Ezcurra, E. (2011) Sampling procedures and species estimation: testing the effectiveness of herbarium data against vegetation sampling in an oceanic island. Journal of Vegetation Science 22:273-280.

Guerin, G.G. and Lowe, A.J. (2013) Multi-species distribution modelling highlights the Adelaide Geosyncline, South Australia, as an important continental-scale arid-zone refugium. Austral Ecology 38: 427-435. 
Herrmann, B. and Hummel, S. (Eds.) (1994) Ancient DNA: recovery and analysis of genetic materials from paleontological, archaeological, museum, medical and forensic specimens. Springer Verlag: New York.

IUCN (2001) IUCN Red List Categories and Criteria. Version 3.1. IUCN Species Survival Commission: Gland/ Cambridge.

Johnson, R.W. (1991) HERBRECS - the Queensland Herbarium records system - its development and use. Taxon 40: 285-300.

Lister, D.L., Bower, M.A. and Jones, M.K. (2010) Herbarium specimens expand the geographical and temporal range of germplasm data in phylogeographic studies. Taxon 59: 13211323.

McAlpine, C.A., Peterson, A. and Norman, P. (2005) The South East Queensland Forest Agreement: Lessons for biodiversity conservation. Pacific Conservation Biology 11: 3-13.

Moerman, D.E. and Estabrook, G.F. (2006) The botanist effect: counties with maximal species richness tend to be home to universities and botanists. Journal of Biogeography 33:19691974.

Neldner, V.J. (1993a) Vegetation Survey and Mapping in Queensland. Queensland Botany Bulletin No. 12.

Neldner, V.J. (1993b) The distribution and habitats of three presumed rare species from Cape York Peninsula. Austrobaileya 4:121-127.

Neldner, V.J. and Butler D.W. (2008) Is $500 \mathrm{~m}^{2}$ an effective plot size to sample floristic diversity for Queensland's vegetation? Cunninghamia 10:513-519.

Neldner, V.J. and Howitt, C.J. (1991) Comparison of an intuitive mapping classification and numerical classifications of vegetation in south-east Queensland, Australia. Vegetatio 94:141-152.

Neldner V.J., Crossley D.C. and Cofinas M. (1995) Using Geographical Information Systems (GIS) to determine the adequacy of sampling in vegetation surveys. Biological Conservation 73:1-17.

Neldner, V.J., Wilson, B.A., Thompson, E.J. and Dillewaard H.A. (2012) Methodology for Survey and Mapping of Regional Ecosystems and Vegetation Communities in Queensland. Version 3.2. Updated August 2012. Queensland Herbarium, Queensland Department of Science, Information Technology, Innovation and the Arts, Brisbane. http://www.ehp.qld.gov au/plants/herbarium/publications/pdf/herbarium_mapping_ methodology.pdf

Queensland Government (2008) State of the Environment Queensland 2007. Environmental Protection Agency, Brisbane.
Queensland Government (2012) State of the Environment Queensland 2011. Environmental Information Systems Unit, Department of Environment and Heritage Protection, Brisbane.

Rivers, M.L., Taylor, L. Brummit, N.A., Meagher, T.R., Roberts, D.L. and Lughadha, E.N. (2011) How many herbarium specimens are needed to detect threatened species? Biological Conservation 144: 2541-2547.

Sattler P.S. and Williams R.D. (eds) (1999) The Conservation Status of Queensland Bioregional Ecosystems. Environmental Protection Agency, Brisbane

Stanton, J.P. (1979) Fraser Island 1:50 000 Vegetation Maps. Queensland Department of Forestry and Queensland National Parks and Wildlife Service, Brisbane.

Sun, D., Hnatiuk, R.J. and Neldner, V.J. (1997) Review of vegetation classification and mapping systems undertaken by major forested land management agencies in Australia. Australian Journal of Botany 45: 929-948.

TERN (2013) TERN Delivers, Version 2.0, February 2013. Terrestrial Ecosystem Research Network. http://tern.org.au/ TERN-delivers-many-kinds-of-infrastructure-bgp2157.html

Thackway, R., Neldner, V. J. and Bolton, M.P. (2008) Vegetation. In McKenzie NJ, Grundy MJ, Webster R and Ringrose-Voase AJ (Eds) Australian soil and land survey handbook: guidelines for surveying soil and land resources (2nd edn). CSIRO Publishing: Melbourne.

Manuscript accepted 22 April 2014 